DOI:

\title{
SEPARAÇÃO DOS PODERES E A EVOLUÇÃO DO ENTENDIMENTO DO STF SOBRE O MANDADO DE INJUNÇÃO
}

\section{SEPARATION OF POWERS AND THE EVOLUTION OF THE VIEW OF THE BRAZILIAN'S SUPREME COURT (STF) ABOUT THE WRIT OF INJUNCTION}

VIDAL SERRANO NUNES JUNIOR Livre-Docente, Doutor e Mestre em Direito Constitucional pela Pontifícia Universidade Católica de São Paulo (PUC-SP). Professor da Faculdade de Direito da PUC-SP e do programa de pós-graduação da Instituição Toledo de Ensino.. Diretor Adjunto da Faculdade de Direito da PUC-SP. Procurador de Justiça. E-mail: serranonunesjr@gmail.com

MARCIO ORTIZ MEINBERG

Doutorando e Mestre em Direito Constitucional pela Pontifícia Universidade Católica de São Paulo (PUC-SP). Professor da Faculdade de Direito da Universidade Ibirapuera (UNIB). Advogado em São Paulo. E-mail: marcio.meinberg@gmail.com

\section{RESUMO}

Trata-se de artigo cujo objetivo é identificar o entendimento do Supremo Tribunal Federal - STF sobre a Separação dos Poderes no que se refere à natureza do Mandado de Injunção, um remédio constitucional a ser concedido em caso de omissão do Poder Público em editar norma regulamentadora necessária para viabilizar o exercício dos direitos e liberdades constitucionais e das prerrogativas inerentes à nacionalidade, à soberania e à cidadania. $\mathrm{O}$ entendimento histórico do STF sobre o tema não é consensual e são percebidas ao menos duas grandes correntes às quais se afiliaram os ministros: Teoria Concretista e Teoria Não-Concretista (além de suas subdivisões). As duas grandes correntes diferenciam-se radicalmente, tanto no que 
DOI:

se refere ao relacionamento entre o Judiciário e os demais Poderes, quanto aos efeitos do Mandado de Injunção. Além disso, o entendimento do STF evoluiu historicamente, não apenas quanto ao posicionamento majoritária da Corte em torno de alguma das teorias, mas também quanto ao desenvolvimento de cada uma delas. A partir da análise das principais decisões do STF sobre o tema, sistematizaremos as características centrais de cada uma das correntes (e como se diferenciam), bem como suas fundamentações e evolução. A metodologia adotada é a Dogmática Jurídica (cf. Alexy e Dreier), com foco nas dimensões empírica (pela análise das decisões do STF) e analítica (estabelecendo definições e sistematizando os conceitos utilizados pelos ministros do STF). Como conclusão, apresentaremos as características centrais de cada uma das teorias adotadas pelo STF no que se refere ao tema Separação dos Poderes.

PALAVRAS-CHAVE: Separação dos Poderes; Mandado de Injunção; Função Normativa.

\section{ABSTRACT}

The purpose of this article is to identify how Supremo Tribunal Federal - STF (Brazilian's Supreme Court) sees the Separation of Powers related to the nature of the Writ of Injunction, a constitutional remedy (relief) to be granted in case of Public Power's omission in enacting a regulatory norm needed to enable the exercise of constitutional rights and freedoms and the prerogatives inherent in nationality, sovereignty and citizenship. The historical opinion of the STF on this subject is not consensual, and there is at least two major currents in which the ministers-judges have joined: Concretist Theory and Non-Concretist Theory (and its subdivisions). The two major currents differ radically, either about the relationship between the Judiciary and the other Powers, as about the effects of the Writ of Injunction. Besides, the STF's opinion has evolved historically, not only regards the majority position of the Court around one of the theories, but also as to the development of each of them. After analysing the main STF's decisions on the subject, we systematize the central characteristics of each of the currents (and how they differ from each other), as well as 
DOI:

their foundations and evolution. The methodology is the Legal Dogmatic (according Alexy and Dreier), with focus on the empirical dimension (the analysis of STF's decisions) and analytical dimension (the establishment of definitions and the systematization the concepts used by the STF's ministers-judges). In conclusion, we present the central characteristics related to Separation of Powers of each one the theories adopted by the STF.

KEYWORDS: Separation of Powers; Writ of Injunction; Normative Function.

\section{INTRODUÇÃO}

O Mandado de Injunção ${ }^{1}$ foi introduzido originalmente pela Constituição Federal de $1988^{2}$. Por se tratar de um instituto novo e sem paralelo no Direito Brasileiro $^{3}$, e diante da ausência de lei que regulamentasse o mandado de injunção, coube ao Supremo Tribunal Federal estabelecer seus parâmetros iniciais.

\footnotetext{
1 Trata-se de um remédio constitucional para suprir "a falta de norma regulamentadora [que] torne inviável o exercício dos direitos e liberdades constitucionais e das prerrogativas inerentes à nacionalidade, à soberania e à cidadania" (CF, art. $\left.5^{\circ}, \mathrm{LXXI}\right)$.

Atualmente o mandado de injunção é disciplinado pela Lei no 13.300/16. Antes da Lei no 13.300/16, o Mandado de Injunção era auto-aplicado diretamente a partir da Constituição Federal sob o mesmo rito do mandado de segurança (entendimento que posteriormente foi formalizado na Lei $n^{\circ}$ 8.038/90, art. 24, parágrafo único).

Em síntese, trata-se de uma ação (individual ou coletiva, cf. Lei $n^{\circ} 13.300 / 16$, art. $1^{\circ}$ ) que pode ser impetrada por quaisquer pessoas que se afirmem titulares dos direitos e liberdades constitucionais e das prerrogativas inerentes à nacionalidade, à soberania e à cidadania, em face do Poder, órgão ou autoridade com atribuição para editar a norma regulamentadora (Lei № 13.300/16, arts. $2^{\circ}$ e $3^{\circ}$ ).

${ }^{2}$ Criado por emenda de iniciativa do Senador Virgílio Távora. Cf. ACKEL FILHO, 1988, p. 101.

3 Manoel Gonçalves Ferreira Filho (FERREIRA FILHO, 2015, p. 355), Celso Bastos \& Ives Gandra Martins (BASTOS, 1988/90, p. 356/357), Hely Lopes Meirelles \& Arnoldo Wald \& Gilmar Ferreira Mendes (MEIRELLES, 2009, p. 287/288) e Flávia Piovesan (PIOVESAN, 1995, p. 160) entendem que o mandado de injunção é uma criação pátria da Constituição de 88, não havendo paralelo em qualquer outro tempo ou lugar.

José Afonso da Silva (AFONSO DA SILVA, 2001, p. 450) e Diomar Ackel Filho (ACKEL FILHO, 1988, p. 102/103) não acompanham este entendimento e identifica a origem do mandado de injunção no direito inglês do século XIV, a partir do instituto do "Equity" (que permite um juízo discricionário na ausência de norma legal ou costume para solucionar a causa), ou no direito norte-americano, no instituto do "writ of injunction" (remédio para impedir violações aos direitos fundamentais).

Por sua vez, Alexandre de Moraes (MORAES, 2002, p. 163), além de reconhecer inspirações no "writ of injunction" norte-americano, também identifica referências no direito português (mas apenas como notificação do órgão omisso).
} 
DOI:

Por muitos anos, uma das principais discussões sobre o mandado de injunção referia-se à natureza jurídica e ao conteúdo das decisões proferidas (e seus efeitos). Diversas teorias foram formuladas (que descreveremos a seguir) e a jurisprudência do Supremo Tribunal Federal variou gradualmente ao longo dos últimos 30 anos. A evolução do posicionamento do STF entre as diferentes teorias também revela a mudança de entendimento da corte sobre os limites da Separação dos Poderes.

\title{
2 PRINCIPAIS TEORIAS SOBRE A NATUREZA JURÍDICA DO MANDADO DE INJUNÇÃO
}

Alexandre de Moraes ${ }^{4}$ sistematiza no esquema abaixo as diversas teorias sobre a natureza jurídica mandado de injunção:

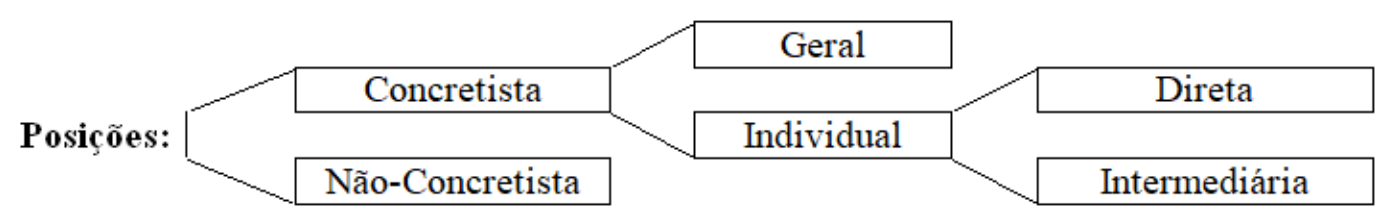

Vidal Serrano \& Marcelo Sciorilli5 resumem as principais teorias da seguinte forma:

\begin{abstract}
Pela posição concretista, uma vez presentes os requisitos do mandado de injunção, o Poder Judiciário expede uma decisão constitutiva, pois, ao mesmo tempo em que declara a existência da omissão normativa, implementa o exercício do direito até que sobrevenha regulamentação por parte do poder competente. A posição concretista se subdivide em duas espécies: a geral e a individual, conforme a abrangência de seus efeitos. Segundo a concretista geral, a decisão judicial terá efeitos erga omnes, com implementação do direito por meio de uma normatividade geral, até o preenchimento da lacuna pelo poder competente. Trata-se de posição pouco aceita na doutrina e na jurisprudência, mercê do entendimento de que o Poder Judiciário, se assim decidisse, estaria usurpando função do Poder Legislativo, o que não se coaduna com o princípio da separação dos Poderes. A corrente concretista individual, por sua vez, apregoa que a decisão proferida na ação injuncional produz efeitos apenas inter partes, isto é, beneficia tão-somente o proponente do mandado, que poderá exercitar plenamente o direito constitucional
\end{abstract}

Segundo Flávia Piovesan (PIOVESAN, 1995, p. 159), também existem doutrinadores que identificam semelhança com o instituto alemão do "Verfassungsbeschwerde", entre eles Adhemar Ferreira Maciel (MACIEL, 1989, p. 133) e Rogério Lauria Tucci \& José Rogério Cruz e Tucci (TUCCI, 1989, p. 151).

${ }^{4}$ MORAES, 2002, p. 169 a 174.

${ }^{5}$ NUNES JUNIOR, 2009, p. 245/247. 
DOI:

pendente de regulamentação normativa. A posição concretista individual admite, ainda, duas subespécies: direta e intermediária. A direta prevê que o Poder Judiciário, ao julgar procedente o mandado de injunção, implemente de imediato o direito constitucional assegurado ao autor. A intermediária preconiza que, ao julgar procedente a ação injuncional, o Poder Judiciário fixe prazo ao órgão ou autoridade competente para a edição da norma regulamentadora. Findo o lapso temporal estabelecido na decisão, e persistindo a inércia, o tribunal deve fixar as condições necessárias ao pleno exercício do direito por parte do autor da ação. Finalmente, a orientação nãoconcretista proclama que o mandamus se destina apenas a declarar a inércia do poder público na regulamentação do preceito constitucional. Segundo essa linha de pensamento, a decisão judicial não se presta a, por si só, estabelecer condições viabilizadoras do exercício do direito constitucionalmente previsto. O conteúdo da decisão proferida em mandado de injunção, para essa corrente, seria semelhante àquele pronunciado nas ações de inconstitucionalidade por omissão.

\title{
3 EVOLUÇÃO HISTÓRICA DO MANDADO DE INJUNÇÃO NO STF
}

\author{
Em 23 de novembro de 1989, na Questão de Ordem no Mandado de Injunção \\ ํo 107/DF6 , houve a primeira decisão do STF sobre a natureza do instituto. Na referida \\ Questão de Ordem assentou-se o entendimento de que caberia ao Judiciário apenas \\ declarar a inconstitucionalidade por omissão (se caracterizada a mora em \\ regulamentar) e desse ciência ao órgão regulamentador, para que este adotasse as \\ providências necessárias. Ou seja, na ocasião o STF adotou a Teoria Não- \\ Concretista. \\ A Teoria Não-Concretista se manteve como tese majoritária pelo menos até \\ 2007. No entanto, durante esse período é possível identificar algumas exceções, \\ como o Mandado de Injunção 232/RJ 7 , o Mandado de Injunção 283/DF8 e o Mandado
}

\footnotetext{
${ }^{6}$ No MI 107/DF, o impetrante objetivava suspender seu licenciamento do Exército por contar com mais de 9 anos de serviço na condição de oficial R2 (temporário), alegando que gozaria de estabilidade caso fosse promulgada a lei prevista no art. 42 , $\$ 9^{\circ}$, da Constituição Federal. O mandado de injunção não foi conhecido por falta de legitimidade ativa do impetrante.

7 No Mandado de Injunção 232/RJ (julgado em 02/08/1991) o impetrante reclamava a imunidade prevista no artigo 195, $\$ 7^{\circ}$, da Constituição Federal, que dependia de regulamentação por lei (inexistente). O STF determinou prazo de seis meses para o Congresso Nacional legislar, sendo que, após o prazo determinado, o impetrante passaria a gozar a imunidade tributária requerida.

${ }^{8}$ No Mandado de Injunção 283/DF (julgado em 14/11/1991) o impetrante buscava reparação por ter sido impedido de exercer atividade profissional durante a Ditadura Militar, o que dependia de lei a ser criada pelo Congresso Nacional no prazo de 12 meses após a promulgação da Constituição Federal, conforme ADCT, art. 8으, § $3^{\circ}$. O STF determinou prazo de 45 dias para o Congresso Nacional legislar e 15 dias para sanção presidencial, sendo que, após o prazo, o impetrante ficava autorizado a requerer reparação constitucional contra a União "pela via processual adequada" (a indenização não foi
} 
DOI:

de Injunção no 284/DF ${ }^{9}$. Nos três exemplos citados, o STF estabeleceu prazo para que o Congresso Nacional ultimasse o processo legislativo da norma reclamada, com consequências jurídicas em caso de persistência da omissão, ou seja, adotou a Teoria Concretista Individual Intermediária. Apesar de, em todos estes casos, a decisão do STF poder ser claramente classificada na Teoria Concretista Individual Intermediária, a maioria dos ministros fez questão de argumentar que a natureza do mandado de injunção era apenas "mandamental" (com ciência ao órgão regulamentador competente) e sem qualquer efeito "constitutivo" (o que é uma absoluta contradição com os efeitos da própria decisão, que são efetivamente constitutivos, ainda que "inter partes").

A partir de 2007, o STF passou a aplicar a Teoria Concretista, individual direta em alguns casos (MI 721) e geral em outros (Ml 670, 708 e 712).

No Mandado de Injunção no 721/DF (julgado em 30/08/2007), diante da ausência da lei complementar prevista no artigo 40, $\$^{\circ}{ }^{\circ}$, da Constituição Federal, foi concedida aposentadoria especial a servidor público utilizando como balizas os mesmos critérios aplicáveis aos servidores do regime geral (Lei no 8.213/91, art. 57, $\S 1^{\circ}$ ), mas apenas para o caso concreto e de forma temporária (conforme Teoria Concretista Individual Direta).

Os Mandados de Injunção 708/DF, 670/ES e 712/PA foram julgados conjuntamente em 25 de outubro de 2007. As três ações versavam sobre o direito de greve dos servidores públicos civis, que deveria ser "exercido nos termos e nos limites definidos em lei específica" (lei esta que até hoje não foi elaborada). O STF modificou radicalmente sua jurisprudência e entendeu que, diante da mora do Congresso Nacional, deveria se aplicar a Lei oㅜ 7.783/89 (Lei de Greve na Iniciativa Privada) enquanto durasse a omissão. Tal decisão teve efeito "erga omnes" para todos os servidores, não apenas os representados pelos sindicatos impetrantes, o que the confere as características da Teoria Concretista Geral. ${ }^{10}$

determinada diretamente pelo STF). Apesar de não ter criado a norma inexistente, o STF autorizou que a reparação fosse pleiteada pelo Código Civil, o que na prática tem o mesmo efeito.

${ }^{9}$ No Mandado de Injunção no 284/DF (de 22/11/1991) o impetrante buscava a mesma reparação do MI 283. Desta vez o STF considerou que o Congresso Nacional já estava em mora, pois já havia sido notificado no Ml 283 e permanecia inerte. Em suma, autorizou o impetrante a requerer a indenização pela via processual adequada, nos mesmos termos da MI 283, mas sem novo prazo.

${ }^{10}$ A partir da adoção da Teoria Concretista pelo STF, houve um sensível aumento na quantidade de mandados de injunção impetrados. Segundo a estimativa elaborada por Maria Cristina Barboza 
DOI:

Por fim, a questão da natureza jurídica do mandado de injunção foi positivada com o advento da Lei no 13.300/16, que adotou a Teoria Concretista Individual Intermediária (e, em casos excepcionais, a Teoria Concretista Geral). De acordo com o rito da Lei no 13.300/16, inicialmente o Judiciário deverá determinar prazo ao órgão omisso para a edição da norma inexistente e, somente se permanecer a omissão, serão estabelecidas pelo Judiciário as condições para o exercício dos direitos prejudicados (Lei ํㅜ 13.300/16, art. 8) com eficácia "inter partes" (Lei ํㅡ⒔300/16, art. 9०, "caput"). Excepcionalmente, quando for indispensável ao exercício do direito, a decisão poderá ter eficácia "ultra partes" ou "erga omnes" (Lei ㄲo 13.300/16, art. 9º, $\left.\S 1^{\circ}\right)$, ou seja, a Teoria Concretista Geral.

\section{SEPARAÇÃO DOS PODERES E MANDADO DE INJUNÇÃO}

Os debates dentro do Supremo Tribunal Federal sobre a natureza do mandado de injunção revelam a opinião dos ministros sobre diversos aspectos da Separação dos Poderes. Identificamos basicamente seis temas principais, conforme:

a) A existência de previsão constitucional para o exercício de função normativa pelo Poder Judiciário (e se há similaridade entre mandado de injunção e ação direta de inconstitucionalidade por omissão);

b) A distinção entre função normativa e função legislativa;

c) Se a decisão em mandado de injunção é aplicável somente ao caso concreto ou se é possível uma decisão abstrata e com efeitos "erga omnes";

d) A supressão da omissão legislativa por meio de aplicação de lei já existente;

e) O exercício de decisões e opções políticas por parte do Poder Judiciário;

e

f) A natureza da comunicação do STF ao Congresso Nacional (se possui força obrigatória e se pode o STF determinar prazo para o Congresso legislar).

(BARBOZA, 2014), a quantidade sobe de 17 (2006) para 51 (2007), depois salta para 141 (2088), chegando ao pico de 1393 (2009), depois mantendo-se em uma média acima de 800 até 2013 (ano final do estudo). 
DOI:

Ao longo deste capítulo sistematizaremos tais discussões e apresentaremos as posições principais dos ministros do STF sobre cada um deles.

\subsection{SOBRE A EXISTÊNCIA DE PREVISÃO CONSTITUCIONAL PARA O EXERCÍCIO DE FUNÇÃO NORMATIVA PELO PODER JUDICIÁRIO (E SOBRE A SIMILARIDADE ENTRE MANDADO DE INJUNÇÃO E AÇÃO DIRETA DE INCONSTITUCIONALIDADE POR OMISSÃO)}

O raciocínio condutor da Teoria Não-Construtivista ${ }^{11}$ é que, em decorrência do Princípio da Separação dos Poderes, o Judiciário só pode exercer uma competência legislativa quando houver expressa ${ }^{12}$ previsão constitucional, e que tal previsão não existe em sede de mandado de injunção ${ }^{13}$. O principal argumento nãoconstrutivista sobre este ponto é a similaridade entre mandado de injunção e ação direta de inconstitucionalidade por omissão.

Tal entendimento foi formulado originalmente pelo ministro Moreira Alves (relator da QO MI 107, aprovado por unanimidade em 23/11/89), que apregoa, em síntese, que o poder de editar resolução com força de lei não foi atribuído ao STF em

\footnotetext{
${ }^{11}$ Cf. QIMI 107/DF, p. 40/41: "Essa solução, acolhida pela Constituição atual, é, sem dúvida alguma, a que se compatibiliza com o sistema constitucional vigente que deu particular relevo à separação de Poderes (arts. $2^{\circ}$, e $60, \S 4^{\circ}, \mathrm{III}$ ), que continuou a inserir entre os direitos fundamentais o de que ninguém é obrigado a fazer ou deixar de fazer alguma coisa senão em virtude da lei (art. 5으. II), e que, também, atento ao princípio democrático, estabeleceu um processo legislativo em que o Poder Judiciário só tem iniciativa legislativa nos casos expressos na própria Constituição e com relação e com relação a matérias a ele estritamente vinculadas, sendo que as decisões políticas de que afinal resultam os textos legais se subordinam a um sistema de freios e contra-freios de que participam exclusivamente os Poderes Legislativo e Executivo, eleitos diretamente pelo povo" (grifo nosso).

12 Cf. QOMI 107/DF, p. 45/46: "Como sucede com o $\S 2^{\circ}$ do artigo 103, em que, na parte inicial ('Declarada a inconstitucionalidade por omissão de medida para tornar efetiva norma constitucional'), apenas se caracteriza quando será admissível tal ação direta (ou seja, quando houver omissão inconstitucional relativa a medida para tornar efetiva norma da Carta Magna), mas não se diz que cabe ao poder Judiciário supri-la legislando ainda que provisoriamente (o que a segunda parte do dispositivo afasta expressamente), o mesmo ocorre com o texto do artigo $5^{\circ}$, LXXI, que se omite quanto à segunda parte do artigo 103, §2을 ficando apenas com norma semelhante à da primeira desta: a em que se caracteriza qual a omissão que dá margem ao uso do mandado de injunção (a fata de norma regulamentadora que torne inviável o exercício dos direitos e liberdades constitucionais e das prerrogativas inerentes à nacionalidade, à soberania e à cidadania), mas, também, não se diz que caberá ao Poder Judiciário, substituindo-se ao Poder competente, fazer essa regulamentação, restrita ao caso concreto, ou extensível a todos os casos análogos" (grifo nosso).

${ }^{13}$ Cf. MI no 232/RJ, p. 44: "[...] se está legislando, sem que a Constituição tenha dado ao Poder Judiciário competência para legislar, competência essa que, no Estado democrático, é dos Poderes Políticos - o Legislativo e o Executivo -, que recebem seus mandatos pelo voto popular".
} 
DOI:

sede de ação direta de inconstitucionalidade por omissão ${ }^{14}$, de modo que não faria sentido concluir que teria sido atribuído em mandado de injunção ${ }^{15}$. Adicionalmente, conclui Moreira Alves que, se nem o STF pode suprir a norma regulamentadora inexistente em sede de ação direta de inconstitucionalidade por omissão, seria um absurdo que outros órgãos do Judiciário, inferiores a ele, pudessem fazê-lo em mandado de injunção ${ }^{16}$.

No mesmo sentido, Maurício Corrêa apontou que ele mesmo foi o deputado constituinte autor da emenda pela qual se concedia competência normativa ao STF, mas que tal proposta não foi aprovada na versão final da Constituição ${ }^{17}$. Por sua vez, Nelson Jobim informou que houve proposta de emenda constitucional que outorgava ao Judiciário a possibilidade de suprir a omissão da norma. Segundo Jobim, a emenda teria sido rejeitada pela Câmara dos Deputados por que tal poder normativo do Judiciário não permitiria exame por qualquer dos outros Poderes ${ }^{18}$.

\footnotetext{
${ }^{14}$ No QOMI 107/DF (p. 39/40), o Ministro Moreira Alves resgata nos anais da Assembleia Constituinte os debates que deram forma à ação direta de inconstitucionalidade por omissão e aponta que, no Substitutivo 1 da Constituição Federal, elaborado pela Comissão de Sistematização (com base no projeto das Comissões Temáticas), existia parágrafo que atribuía ao STF o dever de editar resolução, com força de lei, para suprir inconstitucionalidade por omissão, caso o prazo por ele determinado não fosse atendido pelo poder competente, conforme:

"§ 3ํㅡㄹ Decorrido o prazo aludido no parágrafo anterior sem que seja sanada a omissão, poderá o Supremo Tribunal Federal editar resolução, a qual, com força de lei, vigerá supletivamente."

Ocorre que este parágrafo foi excluído logo no Substitutivo 2 da Comissão de Sistematização, de modo que não consta na versão final da Constituição Federal de 1988.

${ }^{15} \mathrm{Cf}$. QOMI 107/DF, p. 39: "Aliás, do exame da evolução da Constituinte, verifica-se, claramente, que não se deu ao Supremo Tribunal Federal - e o mesmo motivo é bastante para não dá-lo a quaisquer Juízes e Tribunais em mandado de injunção que visasse à regulamentação extensível aos caos análogos - o poder de legislar, ainda que provisoriamente, na ação direita de inconstitucionalidade por omissão em respeito ao princípio da separação dos Poderes, que, na constituição atual, foi incluído entre os princípios imunes ao poder de revisão (artigo 60, $\S 4^{\circ}$, III)" (grifo nosso).

${ }^{16}$ Cf. QOMI 107/DF, p. 43: "Aliás, a admitir-se essa regulamentação, ter-se-á este absurdo: o que o Supremo Tribunal Federal não poderá fazer em ação direta de inconstitucionalidade por omissão, Órgão Judiciário inferior a ele - assim, os Tribunais Superiores ou os Tribunais Regionais - poderá fazê-lo em mandado de injunção".

${ }^{17}$ Cf. MI 543/DF, p. 15: "Sr. Presidente, por época dos debates da Constituinte, apresentei uma emenda pela qual se assegurava poder normativo eficaz ao Supremo Tribunal Federal.

"O deputado Bonifácio de Andrada bateu-se veementemente contra, o que inclusive resultou em acordo para que se incluísse no Texto Constitucional, quando declarada em tese a inconstitucionalidade de norma legal ou ato normativo, a manifestação do Advogado-Geral da União, disposição essa que acabou sendo a ele incorporada pelo $\S 3^{\circ}$ do artigo 103".

${ }^{18}$ Cf. MI 543/DF: "Recentemente, na apreciação da emenda de reforma do Poder Judiciário, a Câmara dos Deputados rejeitou texto em que se pretendia outorgar ao Poder Judiciário a possibilidade de suprir a omissão legislativa. "Falou-se, na discussão da matéria e com finalidade persuasiva, que tal seria a 'medida provisória' do Poder Judiciário. "Com um agravante. "A impossibilidade de exame por qualquer um dos outros poderes".
} 
DOI:

Nenhum dos defensores da Teoria Construtivista discorda (em abstrato) da necessidade de expressa previsão constitucional para o exercício da competência legislativa, apenas das conclusões a partir dela. O ponto central da divergência é que os construtivistas entendem que artigo 5ㅇ, LXXI, da Constituição Federal, atribui competência normativa ao Poder Judiciário ${ }^{19}$. O ministro Eros Grau, inclusive, vai além e afirma que a Constituição não só concedeu tal atribuição ao Judiciário, como se trata de um poder-dever, ou seja, que o STF não pode declinar de sua obrigação de, "no mandado de injunção, formular supletivamente a norma regulamentadora faltante"20 (entendimento semelhante de Ayres Britto ${ }^{21}$ ).

Com relação à similaridade entre mandado de injunção e ação direta de inconstitucionalidade por omissão, Marco Aurélio entende que o paralelismo entre os institutos inexiste, pois isso tornaria ao menos um deles inócuo (já que tem o mesmo efeito) ${ }^{22}$. Por sua vez, Carlos Velloso argumenta que os constituintes foram cautelosos no que toca a ação direta de inconstitucionalidade por omissão (que não atribui competência normativa ao Judiciário), "justamente porque estavam criando na mesma Constituição, o mandado de injunção. Vale dizer, este, no caso concreto, resolveria a questão da omissão"23.

\footnotetext{
${ }^{19}$ Cf. MI no 712/PA, p. 82: "O SENHOR MINISTRO CARLOS BRITTO - Do voto de Vossa Excelência ressai também a compreensão de que o mandado de injunção se inscreve no quadro do sistema de freios e contrapesos, dos mecanismos de freios e contrapesos em favor do Judiciário. Então estamos assumindo esse mecanismo como a Constituição adjudica. "O SENHOR MINISTRO SEPÚLVEDA PERTENCE - Não deixe que o Congresso saiba disso. "O SENHOR MINISTRO CARLOS BRITTO Pelo contrário. É bom que saiba. "O SENHOR MINISTRO SEPÚLVEDA PERTENCE - Quando numa das reformas constitucionais, salvo engano a do Judiciário, propunha-se a fórmula do que se chamou "a solução constitutiva concreta", edição da norma para o caso concreto, até que o legislador editasse a lei. E um deputado disse: "Já estamos sufocados pelas medidas provisórias do Executivo, agora teremos as medidas provisórias do Judiciário". "O SENHOR MINISTRO CARLOS BRITTO Explicitamente deferido ao Poder Judiciário. "O SENHOR MINISTRO GILMAR MENDES - Mas havia senadores também - lembro que ouvi do Senador Pedro Simon - que reclamava do Supremo por não ter assumido a função legislativa que Ihe fora delegada" (grifo nosso).

${ }^{20}$ Cf. MI 721/DF, p. 29: "28. Ademais, não há que falar em agressão à "separação dos poderes", mesmo porque é a Constituição que institui o mandado de injunção e não existe uma assim chamada "separação dos poderes" provinda do direito natural. Ela existe, na Constituição do Brasil, tal como nela definida. Nada mais. No Brasil vale, em matéria de independência e harmonia entre os poderes e de "separação dos poderes", o que está escrito na Constituição, não esta ou aquela doutrina em geral mal digerida por quem não leu Montesquieu no original. 29. De resto, o Judiciário está vinculado pelo dever-poder de, no mandado de injunção, formular supletivamente a norma regulamentadora faltante".

${ }^{21}$ Cf. MI 670/ES, p. 165: "É uma desvantagem para o Judiciário, Ministro Cezar Peluso, porque não se pode obrigar o legislador a legislar, mas o Judiciário é obrigado a julgar. Não podemos tangenciar, temos de dar uma resposta".

${ }_{22}$ MI 219/DF, p. 10.

${ }^{23} \mathrm{MI} 219 / \mathrm{DF}$, p. $13 / 14$.
} 
DOI:

\subsection{SOBRE A DISTINÇÃO ENTRE FUNÇÃO NORMATIVA E FUNÇÃO LEGISLATIVA}

Como desdobramento do ponto anterior, os ministros adeptos da Teoria NãoConcretista sustentam que, no esquema da Separação dos Poderes, as funções normativas são estranhas ao Poder Judiciário. Não estariam entre as atribuições do Poder Judiciário, nas palavras de Moreira Alves ${ }^{24}$, a competência de “regulamentação, 'in concreto' ou 'in abstracto', da norma constitucional dependente de regulamentação", que, segundo Paulo Brossard ${ }^{25}$, seriam "uma tarefa totalmente legislativa".

Um dos principais argumentos, utilizado pelos ministros Aldir Passarinho²6, Celso de Mello ${ }^{27}$, Sepúlveda Pertence ${ }^{28}$ e Maurício Corrêa ${ }^{29}$, é que ao assumir funções normativas, o STF estaria substituindo o legislador.

\footnotetext{
${ }^{24}$ Cf. MI 283/DF p. 47: "[...] em casos excepcionais, quando o Estado se valesse de sua omissão no regulamentar direito, liberdade ou prerrogativa constitucional, seria lícito ao Poder Judiciário impedi-lo disso por medidas concretas (como a suspensão de processo administrativo ou judicial) que não implicassem a regulamentação, 'in concreto' ou 'in abstracto', da norma constitucional dependente de regulamentação" (grifo nosso).

${ }^{25}$ QOMI 107/DF, p. 80.

${ }^{26}$ Cf. MI 219/DF, p. 76: "O entendimento do Supremo Tribunal Federal, nesta matéria, em casos anteriores, foi exatamente de não substituirmos o legislador. Os nossos limites - e o assunto foi largamente examinado e debatido neste Tribunal - não pode ir além daquele fixado, a meu ver, no voto do eminente Relator".

${ }^{27}$ Cf. QOMI 107/DF, p. 58/59: "[...] o mandado de injunção não se destina a constituir direito novo, nem a ensejar ao Poder Judiciário o anômalo desempenho de funções normativas que lhe são institucionalmente estranhas. "O mandado de injunção não é o sucedâneo constitucional das funções político-jurídicas atribuídas aos órgãos estatais inadimplentes. Não legitimam, por isso mesmo, a veiculação de provimentos normativos que se destinem a substituir a faltante norma regulamentadora sujeita a competência, não exercida, dos órgãos públicos. O Supremo Tribunal Federal não se substitui ao legislador ou ao administrador que se hajam abstido de exercer a sua competência normatizadora. A própria excepcionalidade desse novo instrumento jurídico impõe ao Judiciário o dever de estrita observância do princípio constitucional da divisão funcional do Poder".

${ }^{28}$ Cf. MI 670/ES, p. 126: "Deixo apenas assinalado que não recuo das objeções que pus, desde o "leading case" do MI $n^{\circ} 107$, ao que hoje o Ministro Gilmar Mendes chamava um 'protagonismo legislativo do Supremo Tribunal Federal"' a utilizar-se, mancheias, do mandado de injunção para substituir-se ao Congresso".

${ }^{29}$ Cf. MI 670/ES, p. 11: "Ocorre que não pode o Poder Judiciário, nos limites da especificidade do mandado de injunção, garantir ao impetrante o direito de greve. Caso assim procedesse, substituir-seia ao legislador ordinário, o que extrapolaria o âmbito de competência prevista na Constituição".
} 
DOI:

Contrapondo-se ao entendimento de que o exercício da função normativa seria uma violação da Separação dos Poderes, Eros Grau ${ }^{30}$ argumenta que existe uma distinção entre função normativa e função legislativa. A função normativa seria a produção de normas jurídicas, o que inclui não penas a produção de textos normativos (por exemplo, leis), mas também a elaboração de regimentos ou regulamentos ${ }^{31}$. Por sua vez, a função legislativa seria a produção de atos administrativos sob a forma de leis (em sentido formal) ${ }^{32}$.

Gilmar Mendes ${ }^{33}$, por meio da ementa de seu voto, aponta que no direito estrangeiro a adoção de medidas normativas pelo Judiciário não configura violação da Separação dos Poderes. O ministro também aponta que este posicionamento não configura a assunção do STF de um protagonismo legislativo ${ }^{34}$ ou de papel de legislador positivo ${ }^{35}$ e que a tomada de uma solução normativa por meio de mandado de injunção não configura exercício de típica função legislativa ${ }^{36}$.

${ }^{30}$ Cf. MI n 721/DF, p. 24/25: "14. O argumento de que a Corte estaria então a legislar --- o que se afiguraria inconcebível, por ferir a independência e harmonia entre os poderes [art. $2^{\circ}$ da Constituição do Brasil] e a separação dos poderes [art. $60, \S 4^{\circ}$, III] --- é insubsistente. 15. Pois é certo que este Tribunal exercerá, ao formular supletivamente a norma regulamentadora de que carece 0 artigo 40 , $\S 4^{\circ}$, da Constituição, função normativa, porém não legislativa".

${ }^{31} \mathrm{Cf}$. MI no 721/DF, p. 26/27: "21. Afastado, contudo o critério tradicional de classificação das funções estatais, cumpre fixarmos-nos naquele outro, que conduz à seguinte enunciação: "[i] função normativa - de produção das normas jurídicas [= textos normativos]; "[ii] função administrativa - de execução das normas jurídicas; "[iii] função jurisdicional - de aplicação das normas jurídicas. [...] "23. Daí que a função normativa compreende a função legislativa [enquanto produção de textos normativos], a função regimental e a função regulamentar".

${ }^{32} \mathrm{Cf}$. MI no 721/DF, p. 27: "22. A função legislativa é maior e menor do que a função normativa. Maior porque abrange a produção de atos administrativos sob a forma de leis [lei apenas em sentido formal, lei que não é norma, entendidas essas como preceito primário que se integra no ordenamento jurídico inovando-o]; menor porque a função normativa abrange não apenas normas jurídicas contidas em lei, mas também nos regimentos editados pelo Poder Judiciário e nos regulamentos expedidos pelo Poder Executivo".

${ }^{33}$ Cf. MI 708/DF, p. 3: "3.5. Na experiência do direito comparado (em especial, na Alemanha e na Itália), admite-se que o Poder Judiciário adote medidas normativas como alternativa legítima de superação de omissões inconstitucionais, sem que a proteção judicial efetiva a direitos fundamentais se configure como ofensa ao modelo de separação de poderes (CF, art. $\left.2^{\circ}\right)$ ".

${ }^{34}$ Cf. MI 708/DF, p. 28: "Comungo das preocupações quanto à não-assunção pelo Tribunal de um protagonismo legislativo. Entretanto, parece-me que a não-atuação no presente momento já se configuraria quase como uma espécie de 'omissão judicial'".

${ }^{35}$ Cf. MI 708/DF, p. 33: "Por essa razão, não estou a defender aqui a assunção de papel de legislador positivo pelo Supremo Tribunal Federal. "Pelo Contrário, enfatizo tão-somente que, tendo em vista as imperiosas balizas constitucionais que demandam a concretização do direito de greve a todos os trabalhadores, este Tribunal não pode se abster de reconhecer que, assim como se estabelece o controle judicial sobre a atividade do legislador, é possível atuar também nos casos de inatividade ou omissão do Legislativo".

${ }^{36}$ Cf. MI 943/DF, p. 7/8: "Percebe-se que, sem assumir compromisso com o exercício de uma típica função legislativa, o Supremo Tribunal Federal afastou-se da orientação inicialmente perfilhada, no que diz respeito ao mandado de injunção. As decisões proferidas nos Mandados de Injunção n. 283 (Rel. 
DOI:

O ministro Ayres Britto $^{37}$ apresenta outro argumento, de que a função legislativa não é usurpada, tendo em vista que o Congresso Nacional permanece na titularidade de sua competência e pode exercê-la a qualquer momento, enfim legislando. Neste sentido, Joaquim Barbosa ${ }^{38}$ ressalva que o campo de regulamentação pelo Poder Legislativo deve ser preservado ao máximo.

Por sua vez, Eros Grau $^{39}$ também defende que não há substituição do Legislador, pois cabe ao Supremo Tribunal Federal defender a Constituição e, no caso da omissão, "o Legislativo acaba por usurpar função do Poder Constituinte". Apesar disso, Eros Grau reconhece que o exercício da função normativa pelo STF configura "quase uma experiência de legislador" 40 .

\subsection{ATO JUDICIAL APLICÁVEL AO CASO CONCRETO OU ATO JUDICIAL ABSTRATO E COM EFEITOS "ERGA OMNES"}

Um forte argumento utilizado em defesa da tese construtivista é que a viabilização do exercício do direito mediante injunção não viola a Separação dos Poderes, por tratar-se de medida tipicamente judicial e não um ato legislativo, já que a norma criada pelo Judiciário aplicar-se-ia exclusivamente ao caso concreto ${ }^{41}$.

\footnotetext{
Sepúlveda Pertence), 232 (Rel. Moreira Alves) e 284 (Rel. Celso de Mello) sinalizam para uma nova compreensão do instituto e a admissão de uma solução normativa para a decisão judicial".

${ }^{37} \mathrm{Cf}$. MI 712/PA, p. 79: "Bem, de toda maneira, entendo que não há usurpação da função legislativa, não há normatividade supletiva, porque o espaço de normatividade abstrata, o próprio do Congresso Nacional, remanesce à espera do Congresso Nacional, que pode modificar essa lei a que estamos fazendo remissão".

${ }_{38} \mathrm{Cf}$. MI 708/DF, p. 147: "(B) Redução do campo possível de regulamentação pelo Poder Legislativo. Assim, constatada a mora legislativa, creio que se deve preservar ao máximo a liberdade da atividade futura do legislador, que, por sua vez, obviamente deve obediência à Constituição".

${ }^{39}$ Cf. MI 712/PA, p. 83: "Eu me permitiria lembrar uma decisão do Tribunal Constitucional Alemão, de 1958, na qual aquela Corte considera que a omissão reiterada do Poder Legislativo acaba por usurpar função do Poder Constituinte. Porque basta que ele não o regule para que o preceito constitucional não tenha valia nenhuma. É exatamente o que acontece no caso. Não estamos substituindo o Legislativo. Estamos simplesmente fazendo prevalecer a Constituição. Função de guardiões da Constituição".

${ }^{40} \mathrm{Ml} 712 / \mathrm{PA}$, p. 81.

${ }^{41} \mathrm{Em}$ seu voto em Cf. MI 95/RR (p. 7), Carlos Velloso transcreve obra doutrinária própria: "O mandado de injunção, por ter caráter substantivo, faz as vezes da norma infraconstitucional ausente e integra o direito ineficaz, em razão da ausência dessa norma infraconstitucional, à ordem jurídica, assim na linha da lição de Celso Barbi, no sentido de que o juiz cria 'para o caso concreto do autor da demanda uma norma especial', ou adota 'uma medida capaz de proteger o direito reclamado'. Acrescenta o mestre mineiro: 'essa solução está de acordo com a função tradicional da sentença, que é resolver o caso concreto levado ao Poder Judiciário, mas limitando a eficácia apenas a esse caso, sem pretender usurpar funções próprias de outros poderes.' ('As Novas Garantias Constitucionais', RDA, 177/14, 24)".
} 
DOI:

Defendem essa posição os ministros Célio Borja ${ }^{42}$, Carlos Velloso ${ }^{43}$, Rosa Weber ${ }^{44}$ e Ayres Britto ${ }^{45}$.

${ }^{42}$ Cf. MI 232/RJ, p. 42: "Manda o inciso LXXI, do artigo 5, da Constituição, que se viabilize o exercício desse direito mediante injunção ou ordem que é medida tipicamente judicial, não, ato legislativo ou administrativo".

${ }^{43}$ Cf. Ml 1229/DF, p. 13: "[...] A finalidade do mandado de injunção é tornar viável o exercício de direito concedido pela Constituição, cujo exercício está inócuo por falta de norma infraconstitucional. Penso que a Suprema Corte deve elaborar a norma para o caso concreto".

${ }^{44}$ Cf. AgMl 1229/DF, p. 10/11: "Ao conceder o mandado de injunção, deve o Poder Judiciário viabilizar, no caso concreto, o exercício do direito, liberdade ou prerrogativa constitucional que se encontre obstado ante a falta de norma regulamentadora. A concessão do writ injuncional, portanto, não implica - Poder Judiciário na produção, senão na revelação da norma aplicável supletivamente, porque já previsto o direito na Constituição. Exaure-se a prestação jurisdicional na revelação da legislação aplicável à regulamentação do direito, enquanto perdurar a omissão legislativa reconhecida, de modo a viabilizar, na situação concreta, o seu exercício. "Segundo a autorizada liça de Calmon de Passos, ainda, o mandado de injunção "não é remédio certificador de direito, e sim de atuação de um direito já certificado. Seu objeto é exclusivamente definir a norma regulamentadora do preceito constitucional aplicável ao caso concreto, dada a omissão do poder constitucionalmente competente, originariamente, para isso." (Mandado de segurança coletivo, mandado de injunção, habeas data: Constituição e processo. Rio de Janeiro: Forense, 1989, p. 98-9, destaquei). Não cabe, pois, ao Poder Judiciário, em sede de mandado de injunção, substituir-se à autoridade competente para aferir concretamente o preenchimento dos requisitos legais para a aposentadoria especial do impetrante, senão possibilitar o seu exercício indicando a norma aplicável em caráter supletório" (grifos no original).

${ }^{45}$ Cf. MI 708/DF, p. 137: "Essa proposta do Ministro Gilmar é conciliatória: o Judiciário julga, para o caso concreto, indo buscar os seus parâmetros maiores na própria atividade legislativa". 
DOI:

Como reflexo direto deste entendimento, os ministros Marco Aurélio ${ }^{46}$, Cezar Peluso $^{47}$, Ayres Britto ${ }^{48}$, Lewandowski ${ }^{49}$ e Joaquim Barbosa ${ }^{50}$ argumentam que tais decisões aplicáveis ao caso concreto só produzem efeitos "inter partes" (é importante destacar que, apesar de suas manifestações, os votos dos ministros Cezar Peluso e Ayres Britto acompanharam a maioria que concedeu efeitos "erga omnes" aos mandados de injunção no 670,708 e 712).

${ }^{46}$ Cf. MI 721/DF, p. 9/10: "Não se há de confundir a atuação no julgamento do mandado de injunção com atividade do Legislativo. Em síntese, ao agir, o Judiciário não lança, na ordem jurídica, preceito abstrato. Não, o que se tem, em termos de prestação jurisdicional, é a viabilização, no caso concreto, do exercício do direito, do exercício da liberdade constitucional, das prerrogativas ligadas a nacionalidade, soberania e cidadania. O pronunciamento judicial faz lei entre as partes, como qualquer pronunciamento em processo subjetivo, ficando, até mesmo, sujeito a uma condição resolutiva, ou seja, ao suprimento da lacuna regulamentadora por quem de direito. Poder Legislativo. É tempo de se refletir sobre a timidez inicial do Supremo quanto ao alcance do mandado de injunção, ao excesso de zelo, tendo em vista a separação e harmonia entre os Poderes. [...] "Está-se diante de situação concreta em que o Diploma Maior recepciona, mesmo assim de forma mitigada, em se tratando apenas do caso vertente, a separação dos Poderes que nos vem de Montesquieu" (grifo nosso).

${ }^{47}$ Cf. MI 712/PA, p. 164/165: "[...] No caso, o mandado de injunção destina-se a assegurar o exercício do direito que não pode ficar na dependência de demora legislativa. E é, também, meu velho entendimento que a decisão do mandado de injunção significa edição de uma regra singular e concreta, isto é, de uma regra para o caso e para as pessoas vinculadas às relações desse caso" (grifo nosso).

${ }^{48}$ Em seu voto no Ml 670/ES (p. 134), Aires Britto cita prefácio que realizou no livro "Mandado de Injunção", do Professor Carlos Augusto Alcântara Machado: "Com o mérito suplementar de não confundir o exercício da função jurisdicional com a legislativa, pois o novo writ não significa jamais usurpação de competência legiferante. O Judiciário apenas resolve uma questão inter partes (não erga omnes, como é próprio da lei em sentido material) e por nenhuma forma inibe a verdadeira autoridade legiferante de vir a ocupar o espaço normativo até então deixado in albis. É ainda falar: o espaço de normatividade abstrata que é próprio de um poder não jurisdicional permanece à espera desse poder não jurisdicional, a despeito do provimento judicial do mandamus no caso concreto".

${ }^{49} \mathrm{Cf}$. MI 670/ES, p. 136: "[...] Há uma corrente intermediária a qual me filio, que da concreção ao direito pleiteado, no caso concreto, estabelecendo os contornos para o seu exercício. E há a terceira, que é aquela que regula o caso concreto, adotando normas abstratas, até com efeito erga omnes, corrente essa a qual não me associo, exatamente porque entendi, com todo o respeito, que, em trilhando esse caminho, estaríamos, num certo sentido, avançando sobre as competências do Poder Legislativo, o que me parece vedado".

${ }^{50}$ Cf. MI 712/PA, p. 82: "[...] eu conheço e defiro, em parte, e em termos específicos, o presente mandado de injunção, para: [...] (iii) restringir os efeitos desta decisão ao caso concreto". 
DOI:

Tal entendimento não é consenso entre os construtivistas, sendo que os ministros Gilmar Mendes ${ }^{51}$, Luís Roberto Barroso ${ }^{52}$, Menezes Direito ${ }^{53}$ e Eros Grau defendem abertamente a possibilidade de efeitos erga omnes das decisões em mandado de injunção.

Eros $\mathrm{Grau}^{54}$ ensina que, para solucionar o caso concreto objeto do mandado de injunção, o STF deve previamente estabelecer os parâmetros abstratos e gerais, e tais parâmetros podem ser usados para regular todos os casos análogos.

Gilmar Mendes defende a possibilidade de uma "regulação provisória" por parte do Poder Judiciário, com eficácia erga omnes ${ }^{55}$. Contudo, o ministro apresenta

51 Cf. MI 943/DF, p. 10/11: "As decisões acima referidas [MI 758, MI 712 e MI 708] indicam que o Supremo Tribunal Federal aceitou a possibilidade de regulação provisória pelo próprio Judiciário, uma espécie de sentença aditiva, se se utilizar a denominação do direito italiano. [...] "Interessante ressaltar, ainda, a extensão possível dos efeitos advindos de decisão em mandado de injunção. $O$ que se evidencia é a possibilidade de as decisões nos mandados de injunção gerarem efeitos concretos não somente em razão do interesse jurídico de seus impetrantes, estendendo-os também aos demais casos que guardem similitude. Assim, em regra, a decisão em mandado de injunção, ainda que dotada de caráter subjetivo, comporta uma dimensão objetiva, com eficácia erga omnes, que serve para tantos quantos forem os casos que demandem a concretização de uma omissão geral do Poder Público, seja em relação a uma determinada conduta, seja em relação a uma determinada lei".

${ }^{52}$ Cf. Ml 833/DF, p. 70/71: "Ministro Gilmar, permita-me só um complemento. Nós estamos lidando com a omissão legislativa. Nós dois achamos, doutrinariamente, e o Tribunal tem decidido que, em hipótese em que exista a frustração de um direito inequívoco por omissão legislativa, o Judiciário pode expandir a sua atuação e editar a norma faltante. Mas eu acho que esta é uma competência que nós temos que exercer com parcimônia. Portanto, se o direito não é inequívoco, eu acho que nós devemos deferir ao legislador. Essa é a posição que eu estou propondo e vejo que é a posição do Ministro Gilmar, para o meu conforto".

${ }^{53} \mathrm{Cf}$. Ml 708/DF, p. 89: "Ao converso do que se poderia pensar, entendo que a utilização desse instrumento, posto à disposição dos julgadores, reforça a ideia da separação de poderes, porque se está utilizando um instrumento legislativo, uma norma legislativa, uma norma estatal, como costuma dizer o Ministro Celso de Mello, para cobrir a ausência que inviabiliza o exercício de direito que a Constituição prescreve".

${ }^{54}$ Cf. MI 721/DF, p. 28/29/30/31: "25. De resto, é ainda certo que, no caso de concessão do mandado de injunção, o Poder Judiciário formula a própria norma aplicável ao caso, embora ela atue como novo texto normativo. "26. Apenas para explicitar, lembro que texto e norma não se identificam. O que em verdade se interpreta são os textos normativos; da interpretação dos textos resultam as normas. A norma é a interpretação do texto normativo. A interpretação é atividade que se presta a transformar textos --- disposições, preceitos, enunciados --- em normas. "27. O Poder Judiciário, no mandado de injunção, produz norma. Interpreta o direito, na sua totalidade, para produzir a norma de decisão aplicável à omissão. É inevitável, porém, no caso, seja essa norma tomada como texto normativo que se incorpora ao ordenamento jurídico, a ser interpretado/aplicado. Dá-se, aqui, algo semelhante ao que se há de passar com a súmula vinculante, que, editada, atuará como texto normativo a ser interpretado/aplicado. [...] "Esses parâmetros hão de ser definidos por esta Corte de modo abstrato e geral, para regular todos os casos análogos, visto que norma jurídica é o preceito, abstrato, genérico e inovador --- tendente a regular o comportamento social de sujeitos associados --- que se integra no ordenamento jurídico e não se dá norma para um só. "32. No mandado de injunção o Poder Judiciário não define norma de decisão, mas enuncia a norma regulamentadora que faltava para, no caso, tornar viável o exercício do direito da impetrante, servidora pública, à aposentadoria especial. "

55 Cf. MI 712/PA, p. 69: "Com eficácia erga omnes, até porque não imagino que possamos nos transformar num tipo de Justiça trabalhista para as greves dos servidores". 
DOI:

um argumento essencialmente prático: se o STF se dedicasse a emitir decisão restrita a cada juízo concreto, milhões de casos similares seriam levados à Corte ${ }^{56}$. Por fim, Gilmar Mendes alerta para que essa "imiscuição" na esfera legislativa para a produção de normas somente seja exercida com respeito a "um quadro de institucionalidade" 57 (e exemplifica com diversas decisões em que, apesar do apelo ao legislador, o Congresso permaneceu em inércia).

No mesmo sentido, o ministro Luís Roberto Barroso ${ }^{58}$ propõe que tal prerrogativa seja exercida "com parcimônia" (sem definir ou sugerir parâmetros para a "parcimônia").

As principais críticas contrárias aos efeitos "erga omnes" em mandado de injunção vêm de Lewandowski ${ }^{59}$, que reconhece a necessidade de "superar uma visão estática, tradicional, do princípio da Separação dos poderes", mas sem avançar "sobre

${ }^{56}$ Cf. AgMl 1229/DF, p. 12: "Senhor Presidente, a propósito deste tema, eu já tive a oportunidade de me manifestar quanto à necessidade de que nós adotemos um outro encaminhamento, porque estamos fazendo justiça às partes, como o que se reclama é uma disciplina normativa. Eu fico a imaginar se, em cada caso que nós tivermos, a propósito de mandado de injunção, nós ficarmos emitindo esse juízo concreto que, a rigor, não é sequer um juízo concreto, manda apenas que se faça a aferição segundo os termos da legislação previdenciária. Então, me parece que nós temos que encontrar um outro encaminhamento para estes mandados de injunção, porque também esse procedimento será aplicável a outras matérias. Imagine que amanhã se trate de adicional de insalubridade, adicional de aviso prévio ou seja lá o que for, e o Tribunal tenha que responder a milhões de casos quando, de fato, o que se reclama é uma legislação que viabilize esse direito".

${ }^{57}$ Cf. MI 712/PA, p. 109: "Em outras palavras, estou a dizer o seguinte: não acho que, a priori, a partir da verificação de uma omissão, deva o Tribunal imiscuir-se, na esfera legislativa desde logo produzir normas. Evidente, há todo um quadro de institucionalidade a ser respeitado. "No entanto, conforme vimos e tive a oportunidade de elencar, são inúmeros os pronunciamentos desta Corte - citei o MI no 20, Ministro Celso de Mello; MI no 485, Ministro Maurício Corrêa; MI no 585, Ministro Ilmar Galvão. Todas essas decisões se limitavam a fazer apelos ao legislador; conforme sabemos, os apelos caíram no vazio por conta da convergência de visões que levaram a essa inoperância".

${ }^{58}$ Cf. MI no 833/DF, p. 70/71: "Ministro Gilmar, permita-me só um complemento. Nós estamos lidando com a omissão legislativa. Nós dois achamos, doutrinariamente, e o Tribunal tem decidido que, em hipótese em que exista a frustração de um direito inequívoco por omissão legislativa, o Judiciário pode expandir a sua atuação e editar a norma faltante. Mas eu acho que esta é uma competência que nós temos que exercer com parcimônia. Portanto, se o direito não é inequívoco, eu acho que nós devemos deferir ao legislador. Essa é a posição que eu estou propondo e vejo que é a posição do Ministro Gilmar, para o meu conforto" (grifo nosso).

${ }^{59}$ Cf. MI 670/ES, p. 79/80: "Para que isso ocorra, não há dúvida, é preciso superar uma visão estática, tradicional, do princípio da separação dos poderes, reconhecendo-se que as funções que a Constituição atribui a cada um deles, na complexa dinâmica governamental do Estado contemporâneo, podem ser desempenhadas de forma compartilhada, sem que isso implique a superação da tese original de Montesquieu. "Não vou tão longe, porém, a ponto de ultrapassar a finalidade do mandado de injunção - que é, nas palavras de José Afonso da Silva, a de 'realizar concretamente em favor do impetrante o direito, liberdade ou prerrogativa sempre que a norma regulamentadora torne inviável seu exercício' - , avançando sobre a própria razão de ser do Poder Legislativo, ao qual compete expedir normas de caráter geral e abstrato para regular determinadas situações ocorrentes na realizada fenomênica". 
DOI:

a própria razão de ser do Poder Legislativo, ao qual compete expedir normas de caráter geral e abstrato". Segundo o ministro, a edição de normas abstratas e de caráter geral pelo STF seria uma forma de legislar ${ }^{60}$, o que resultaria na desfiguração $0^{61}$ do mandado de injunção e invasão do espaço atribuído a outro Poder ${ }^{62}$.

\subsection{SOBRE A SUPRESSÃO DA OMISSÃO LEGISLATIVA POR MEIO DE APLICAÇÃO DE LEI JÁ EXISTENTE}

Um raciocínio utilizado em prol da Teoria Concretista (ainda que defendido indiretamente por ministros adeptos da Teoria Não-Concretista) é que o STF não estaria legislando quando apenas indicasse a norma a ser aplicada, deixando a solução do caso para outras instâncias do Poder Judiciário. Esse foi o mesmo entendimento que guiou as decisões nos mandados de injunção no 283 e 284 e que também pode ser identificado nos mandados de injunção no 708,670 e 712.

Ayres Britto ${ }^{63}$ entende que, em ambos os casos não há legiferação, pois o STF está apenas aplicando lei já existente, sem introduzir nova norma no sistema.

\footnotetext{
${ }^{60}$ Cf. MI 708/DF, p. 95/96: "E formal. Entendo que o mandado de injunção regula caso concreto e não se pode, digamos assim, estabelecer uma regra, ou tomar uma regra geral abstrata e, enfim, até legislar".

${ }^{61}$ Cf. MI 708/DF, p. 80: "[...] quer me parecer que tal solução, insisto, representaria indevida ingerência do Judiciário na competência privativa do Congresso Nacional de editar normas abstratas e de caráter geral, além de desfigurar o mandado de injunção, importante instrumento concebido pelo constituinte para regular, caso a caso, o exercício de direito, liberdade ou prerrogativa assegurados na Carta Magna".

${ }^{62}$ Cf. MI 708/DF, p. 77: "Pareceu-me, também, naquele momento, que a solução de aplicar-se a Lei $7.783 / 89$ ao caso sob exame, ainda que com algumas modificações pontuais, representaria um avanço indevido do Judiciário em seara atribuída a outro Poder, não havendo o que diferenciasse tal decisão de uma típica função legislativa. "Observei, então, que a Poder Legislativo compete expedir normas de caráter geral e abstrato para regular determinadas situações ocorrentes na realidade fenomênica, não me parecendo legítimo que esta Corte, a pretexto de viabilizar o exercício de direito fundamental por parte de determinada pessoa ou grupo de pessoas, no âmbito do mandado de injunção, pudesse expedir regulamentos para disciplinar, em tese, tal ou qual situação, ou adotar diploma normativo vigente aplicável a situação diversa. Tal risco parecia-me ainda mais preocupante caso se pretendesse emprestar eficácia erga omnes à decisão, como aventado à oportunidade".

${ }^{63}$ Cf. MI 712/PA. p. 77/78: "E, aí, fugimos do debate. Parece-me ser complicado, ainda, é muito difícil obter um consenso de que vamos suprir uma omissão legislativa exercendo uma atividade legiferando. Não há uma função normativa quando decidimos nesse caso. Baixamos um provimento, tomando de empréstimo uma lei fruto da atividade legislativa do Congresso Nacional. [...] Muito bem. E essa decisão implica legislar? Acho que não".
} 
DOI:

Sepúlveda Pertence ${ }^{64}$ diverge radicalmente, pois em seu entendimento existe uma diferença crucial entre os dois conjuntos de casos. Nos mandados de injunção no 283 e 284 a decisão apenas indicou que os impetrantes poderiam buscar a reparação pleiteada pela via processual adequada, sem indicar lei material que o determinasse (na ausência da lei específica, seria utilizada a lei geral, ou seja, o Código Civil). Por outro lado, nos mandados de injunção № 708, 670 e 712 o STF indicou caminho semelhante, mas determinando a incidência de lei que expressamente não se aplicaria ao caso (seria a aplicação, aos servidores públicos, da lei de greves dos trabalhadores da iniciativa privada). Ao aplicar uma lei expressamente inaplicável, o STF teria alterado seu teor, o que configuraria atividade legiferante.

É interessante observar que mesmo esta solução não agrada a Marco Aurélio $^{65}$, para quem o STF deveria solucionar diretamente o caso (ainda que com uso de outra lei), sem delegar a decisão concreta a outras instâncias do Judiciário.

\subsection{SOBRE O EXERCÍCIO DE DECISÕES E OPÇÕES POLÍTICAS POR PARTE DO PODER JUDICIÁRIO}

Outro ponto apresentado pelos ministros do STF de posição Não-Concretista (entre eles, Moreira Alves e Sepúlveda Pertence) é que as matérias constitucionais (por exemplo, o número dos deputados das unidades federativas) ${ }^{66}$ que dependem de lei, representam "opção política deixada ao Congresso" 67 e ao Executivo, visto que

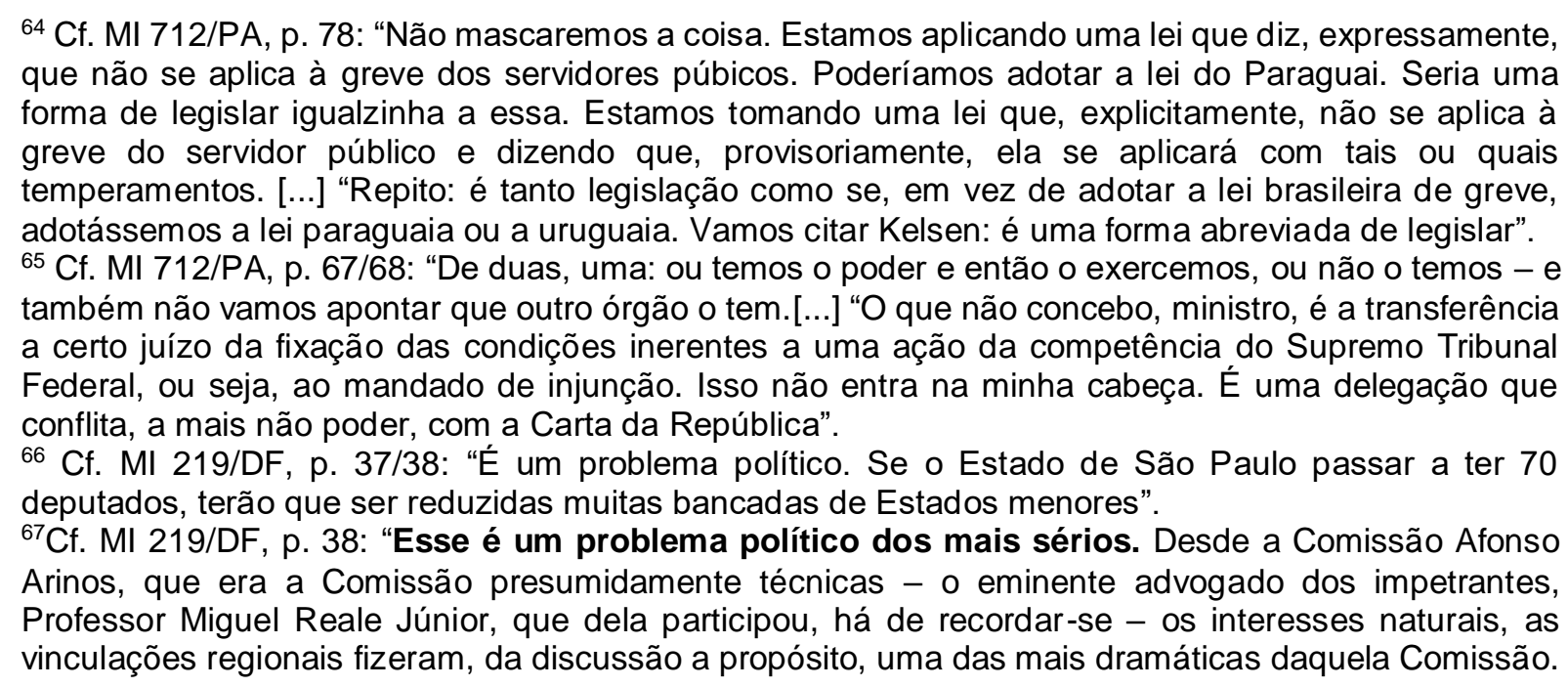


DOI:

são estes Poderes eleitos diretamente pelo povo (diferente do Poder Judiciário) ${ }^{68}$. Assim, "o que não cabe, efetivamente, é o Supremo Tribunal Federal se substituir, desde logo, ao Congresso Nacional numa decisão eminentemente de natureza política [...]"69.

Em suma, neste tema discute-se se, além do aspecto formal (Judiciário exercer uma função normativa, independente do tema), há um aspecto material (que o Judiciário não poderia exercer uma função normativa relacionada a "opções políticas"). Vale esclarecer que os ministros que utilizam o argumento da "opção política deixada aos Poderes eleitos" são todos adeptos da Teoria Não-Concretista, ou seja, trata-se de um reforço ao aspecto formal e não o estabelecimento de uma exceção. Tais ministros não defendem (muito pelo contrário) a possibilidade do Judiciário exercer função normativa cujo conteúdo não seja considerado uma "opção política".

Sepúlveda Pertence ${ }^{70}$ também argumenta que a omissão legislativa muitas vezes decorre do processo democrático, ou seja, não se trata de inércia (o Poder Legislativo não teria editado a norma exatamente por não ter atingido ainda o consenso mínimo necessário para formar uma maioria sobre o tema). Neste sentido, o ministro vai até mais além e defende, inclusive, a prerrogativa do Congresso Nacional em não legislar ${ }^{71}$, ou seja, manter deliberadamente um caso sem normatização.

Pois bem, a fórmula do art. 45 foi daquelas composições de adiamento de um problema. O que se teve, ai, foi um limite máximo (justo ou injusto, não é hora de cogitar), da ampliação da futura representação de São Paulo, até 70. Veja V.Ex. a que é uma opção política delicadíssima. [...] "Chegar ao teto foi uma opção política deixada ao Congresso. Não foi à-toa que o Congresso disse que nenhum Estado terá menos de oito e que o número de Deputados do maior não ultrapassará 70 . $\mathrm{E}$, não, que o maior Estado terá 70" (grifos nossos).

${ }^{68} \mathrm{Cf}$. QOMI no 107/DF, p. 40/41: "[...] as decisões políticas de que afinal resultam os textos legais se subordinam a um sistema de freios e contra-freios de que participam exclusivamente os Poderes Legislativo e Executivo, eleitos diretamente pelo povo".

${ }^{69} \mathrm{MI}$ no 219/DF, p. 39/40.

${ }^{70}$ Cf. MI 670/ES, p. 126/127: "Muitas vezes a demora do processo legislativo não é um problema de inércia, não é um problema de falta de vontade de legislar; é a impossibilidade política de chegar-se a uma fórmula aceita. E isso é do jogo democrático. E isso é, sobretudo, a grande virtude do processo legislativo democrático. [...] "Algumas vezes, o papel do Supremo Tribunal, se não é de protagonismo legislativo, é, no entanto, de acicatar aos poderes políticos para o dever de dar efetividade à Constituição".

${ }^{71} \mathrm{Cf}$. MI 712/PA, p. 75: "Sou muito respeitoso à prerrogativa, ao poder, que é do Congresso, de não legislar em determinadas matérias. Todos o sabemos e tivemos aqui os esclarecedores depoimentos pessoais do ministro Nelson Jobim sobre os compromissos dilatórios que fazem parte do processo político $[\ldots] "$. 
DOI:

O ministro Aldir Passarinho identifica uma especificidade no MI 219, que reforça o argumento da "opção política". Na Carta de 69 (Emenda Constitucional no 01/69), o objeto específico desta ação (determinação do número dos deputados por estado, conforme critério proporcional) era de fato de competência do Poder Judiciário (mais especificamente do Tribunal Superior Eleitoral), porém tal função normativa foi retirada do Judiciário pelo constituinte na Constituição de $88^{72}$. Em suma, teria havido uma decisão, pela qual a Assembleia Constituinte deliberadamente identificou o tema como "opção política" concedida ao Legislativo.

No entanto, Aldir Passarinho deixou de esclarecer um ponto fundamental: a redação original do artigo $39, \S^{\circ}{ }^{\circ}$, da Carta de 69 , previa que o número de deputados por Estado seria estabelecido em lei, e não pelo TSE. Foi somente em 1977, por meio de emenda constitucional, que tal atribuição foi transferida para a Justiça Eleitoral (por meio da Emenda Constitucional no 8/77, mantida pelas Emendas Constitucionais nำ22/82 e nำ25/85).

O ministro Sydney Sanches, por sua vez, na MI 20/DF (julgada em 19/05/1994), sobre a greve dos servidores públicos, entende que "essas questões a Constituição quer que o Congresso Nacional resolva. E não por lei ordinária, mas, sim, por Lei Complementar, que exige aprovação por maioria absoluta (art. 69)"73. Ou seja, também constituiria "opção política" reservada ao Legislativo. Porém Sydney Sanches não esclarece qual o critério para incluir a greve dos servidores entre as "opções políticas". Uma análise literal de sua manifestação poderia levar à compreensão de que todo tema reservado por lei (ou eventualmente por lei complementar) configuraria uma "opção política" (neste caso, novamente o aspecto formal e material estariam vinculados).

Uma manifestação em sentido contrário (ou seja, Concretista), veio de Rosa Weber $^{74}$, que reconhece que "a escolha política não cabe, em princípio, ao Poder

\footnotetext{
72 Cf. MI 219/DF, p. 76: "O Tribunal Superior Eleitoral que tinha essa faculdade, como disponha o $\S 2^{\circ}$ do art. 39 da Carta Política anterior a Constituição nova não mais conferiu tal atribuição àquela Corte, e não pode este Tribunal substituir o legislador, já que o $\S 1^{\circ}$ de seu art. 45 expressamente prevê que tal lei complementar é que estabelecerá a proporcionalidade".

${ }^{73} \mathrm{Ml}$ 20/DF, p. 53.

${ }^{74} \mathrm{Cf}$. MI 833/DF, p. 86: "Ministro Fux, trata-se de um conceito legal, e, por isso, ele sempre resulta de uma escolha política. Não tenho a menor dúvida de que a escolha política não cabe, em princípio, ao Poder Judiciário. Ela cabe a quem? Ao Poder Legislativo. Ocorre que, havendo omissão do legislador
} 
DOI:

Judiciário", mas, havendo omissão, a Constituição autoriza o "preenchimento das lacunas pelo Poder Legislativo". Ou seja, não entende que a "opção política" seja um empecilho para o exercício da função normativa pelo Judiciário em sede de mandado de injunção.

\subsection{SOBRE A NATUREZA DA COMUNICAÇÃO DO STF AO CONGRESSO NACIONAL}

Além da discussão central sobre o exercício direto da função normativa por parte do Poder Judiciário, a análise da jurisprudência do STF permite identificar um tema lateral, mas também relevante para a Teoria da Separação dos Poderes: a natureza da comunicação do STF ao Congresso Nacional. Este tema lateral também se desenvolve em duas discussões: se tal comunicação do STF possui força obrigatória; e se o STF pode determinar prazo para o Congresso Nacional.

\subsubsection{Sobre a força obrigatória da comunicação ao Poder Legislativo}

Um tema fundamental sobre Separação dos Poderes em mandado de injunção refere-se à força obrigatória (ou não) da comunicação do STF ao Poder Legislativo.

Entre os que advogam pela natureza obrigatória de tal comunicação, com destaque para Sydney Sanches e Néri da Silveira, a decisão do STF é impositiva mesmo ao Poder Legislativo, que haverá de cumpri-la em homenagem ao princípio da independência e harmonia entre os Poderes ${ }^{75}$, pois "os Poderes da República coexistem de forma harmônica, e nunca uma decisão desta Corte [STF] foi descumprida por outro Poder da República"76 Além disso, não é cabível a presunção

\footnotetext{
por mais de duas décadas, há instrumentos processuais - assegurados na Constituição - para o preenchimento das lacunas pelo Poder Legislativo. Mas seria só nessa linha".

${ }^{75} \mathrm{Cf}$. QOMI 107/DF, p. 85: "Regulamentação que não se pode presumir não venha a ocorrer, se o mandado de injunção vier a ser deferido, face ao caráter mandamental, impositivo, do julgado, ao princípio constitucional da independência e harmonia entre os Poderes e aos que garantem, por todas as formas e meios, o respeito institucional à coisa julgada".

${ }^{76}$ Cf. MI 219/DF, p. 39: "Ai é problema de relacionamento de Poderes. Não cabe partir dessa presunção. V.Exa. sabe que, no sistema alemão, também não existe prazo, em hipótese semelhante e é essa mesma indagação que V.Exa. encontra nos livros de doutrina alemã: e se o Congresso não quiser? A
} 
DOI:

de que o Congresso Nacional não atenderia uma decisão do STF, mas isso certamente constituiria um "problema de relacionamento de Poderes"77.

Apesar de seu posicionamento tão categórico no MI 219 (de 22/08/1990), o ministro Néri da Silveira posteriormente se tornaria o principal defensor da Teoria Concretista Intermediária, que estabelece prazo para o Legislativo ultimar a norma, com consequências em caso de descumprimento ${ }^{78}$. Ou seja, passou a aceitar a possiblidade de descumprimento de uma decisão do STF pelo Congresso Nacional.

Ainda que não acompanhe a posição que identifica como mandamental a natureza da decisão do mandado de injunção, no MI 219 (julgado em 22/08/90) o ministro Marco Aurélio reconhece que, se notificado a suprir a omissão legislativa, o Congresso Nacional cumprirá a decisão do STF ${ }^{79}$. Alguns anos depois, no MI 361 (julgado em 08/04/1994), o ministro muda de posição ${ }^{80}$ (até porque já havia casos práticos em que, mesmo notificado pelo STF, o Congresso deixou de emitir a norma necessária).

Por sua vez, o ministro Aldir Passarinho entende que a decisão do STF em mandado de injunção não possui força coercitiva ${ }^{81}$, sendo mera comunicação ao

resposta é: não se pode jamais supor que o Congresso não atenda a uma decisão da Corte Constitucional".

${ }^{77}$ Cf. MI 219/DF, p. 43: "Ai é problema de relacionamento de Poderes. Não cabe partir dessa presunção. V.Exa. sabe que, no sistema alemão, também não existe prazo, em hipótese semelhante e é essa mesma indagação que V.Exa. encontra nos livros de doutrina alemã: e se o Congresso não quiser? A resposta é: não se pode jamais supor que o Congresso não atenda a uma decisão da Corte Constitucional".

${ }^{78}$ Cf. MI 20/DF, p. 55: "Fixo-lhe, porém, um prazo, eis que, em mora, é preciso que a autoridade ou o órgão legislativo cumpram seu dever previsto na Constituição e editem a norma. Compreendo, dessa maneira, que, vencido o prazo sem edição da norma regulamentadora, podem aqueles cujo direito não é exercitado por falta da norma e que vêm ao Poder Judiciário pedir lhes assegure o exercício do direito previsto na Constituição, caso em que o Tribunal, em conhecendo da reclamação, decide a hipótese concreta" (grifo nosso).

${ }_{79}$ Cf. Ml 219/DF, p. 40: "Senhor Presidente, todos acreditamos na assunção das respectivas responsabilidades pelos Poderes da Nação. No dia em que não crermos nisso, estaremos muito mal. Creio que, no caso, não temos provimentos judiciais totalmente inócuos. Comungo com V. Ex. ${ }^{a}$ entendendo, até mesmo diante do princípio da razoabilidade que o Congresso Nacional será sensível aos pronunciamentos do Supremo Tribunal Federal".

${ }^{80} \mathrm{Cf}$. MI 361/RJ, p. 19: "Não posso, Senhor Presidente, fixar um prazo para posteriormente surgir um impasse, caso não seja observado pelo Congresso Nacional, numa atividade precípua, uma atividade que é política do Poder Legislativo, e a decisão do Supremo Tribunal Federal cair no vazio, ser motivo de descrédito para a atuação da própria Corte".

${ }^{81} \mathrm{Cf}$. QOMI no 107/DF, p. 98/99: "Por certo que o instituto processual-constitucional em exame, poderá, apesar das decisões judiciais reconhecendo a omissão da autoridade competente para o exame da norma e declarando que ela deva ser expedida, trazer frustrações, pela impossibilidade que pelo menos em certos casos - e serão certamente muitos - a não expedição das regras normativas viabilizadoras 
DOI:

Poder Legislativo. Aldir Passarinho fundamenta seu entendimento na obra de Galeno Lacerda ("Proteção Processual dos Direitos Fundamentais"), que professa não caber ao Judiciário "compelir o Legislativo a elaborar normas legais, porque a natureza e a técnica das funções desse Poder não se compadecem com o tipo de constrição específica de uma ordem judicial" ${ }^{2}$.

Enfim, o ministro Carlos Velloso aponta que existe a possibilidade do Congresso permanecer em inércia, o que representaria um "desfavor da harmonia dos Poderes" 83 . Trata-se de argumento em favor da Teoria Concretista, na qual não haveria qualquer comunicação ao Congresso Nacional, de modo que nada poderia ser descumprido.

É importante observar que, com relação ao Poder Executivo, a discussão sobre a força obrigatória da comunicação não é levantada.

\subsubsection{Sobre o prazo estabelecido ao Poder Legislativo pelo STF}

Uma evolução da discussão anterior (natureza mandamental ou mera ciência para o Poder Legislativo) é a possibilidade de ser estabelecido um prazo a ser observado pelo Poder Legislativo. De um lado perfilam os ministros que entendem que o simples estabelecimento de um prazo já seria uma afronta à Separação dos Poderes, enquanto do outro lado alinham-se os ministros que entendem ser possível estabelecer um prazo sem penalidade (uma espécie de coação indireta).

do direito constitucional, pela ausência de força coercitiva, inerente às decisões judiciais, para que seja efetivamente suprida a omissão".

${ }^{82}$ Cf. QO MI 107/DF, p. 100: "Não se pode, porém, pensar em mandado de injunção para compelir o Legislativo a elaborar normas legais, porque a natureza e a técnica das funções desse Poder não se compadecem com o tipo de constrição específica de uma ordem judicial. E preciso não esquecer que as normas constitucionais devem ser interpretadas segundo o princípio da independência dos poderes. (fls 151/152)".

${ }^{83}$ MI 219/DF, p. 49. 
DOI:

Para os ministros do STF que recusam a imposição do prazo, com destaque para os ministros Octávio Gallotti ${ }^{84}$, Marco Aurélio ${ }^{85}$, Cármen Lúcia ${ }^{86}$ e Maurício Corrêa ${ }^{87}$, da mesma forma que nas ações diretas de inconstitucionalidade por omissão não há prazo para o Legislativo, então não caberia que houvesse tal prazo no mandado de injunção (diferente dos órgãos administrativos, cujo prazo é previsto). Gallotti ressalta que ao STF cabe apenas "dar ciência, dessa situação de mora, ao Congresso Nacional” 88 (sem estipulação de prazo). Por sua vez, Marco Aurélio aponta que "um Poder não compele o outro a atuar no campo pertinente à atividade precípua, muito menos the assinando prazo para tanto" 89 , pois ai sim "haveria a quebra da harmonia entre os Poderes" 90 .

Por outro lado, no MI 283 (julgado em 20/03/1991), diversos ministros do STF, entre eles Moreira Alves, Sepúlveda Pertence e Sydney Sanches, entendem ser legítimo o estabelecimento de um prazo para o Congresso Nacional legislar, desde que sem penalidade. Segundo tal entendimento, a fixação do prazo não viola a Separação dos Poderes, pois o STF não está impondo ${ }^{91}$ ou "ordenando ao Congresso

${ }^{84}$ Cf. MI 219/DF, p. 31/32: "Abstenho-me de assinar prazo ao Congresso Nacional, para a elaboração legislativa em causa, tendo em vista o entendimento analogicamente recolhido do $2^{\circ}$ do art. 103 da Constituição, que, tratando da declaração de inconstitucionalidade por omissão, só cogita de prazo quando se cuida de órgão administrativo".

${ }^{85}$ Cf. MI no 284/DF, p. 11/12: "Ademais, não cabe ao Poder Judiciário assinar prazo para que o Legislativo edite o diploma reclamado pela Carta. Trata-se de atividade inerente a um Poder e que é definida no âmbito político. Esta assertiva tem o respaldo da previsão do §2 do artigo 103 da Lei Básica, segundo a qual, declarada a inconstitucionalidade por omissão, cumpre tão-somente dar ciência ao Poder Legislativo".

${ }^{86} \mathrm{Cf}$. MI no 833/DF, p. 27: "Até para Vossa Excelência pensar sobre a proposta do Ministro Gilmar, a qual eu peço vênia para não aderir. Acho que quando a Constituição fixou o prazo, nos casos de controle de constitucionalidade por omissão, fixou apenas para os órgãos administrativos, ou seja, não quis que o Poder Judiciário fixasse prazos para o Poder Legislativo. Em segundo lugar, seria uma inovação que o Supremo estaria admitindo mudando integralmente o entendimento até aqui adotado, inclusive das relações entre os Poderes. E segundo, porque, objetivamente, estamos numa quadra eleitoral em que as dificuldades, portanto, para votação são muito maiores e nós teríamos, portanto, não a solução de imediato nem adiantaria muito fixar prazo porque o Supremo fixa um prazo e se o Congresso não cumprir, e aí? Fazemos o quê? Daí porque peço vênia para não aderir".

${ }^{87} \mathrm{Cf}$. MI 670/ES, p. 11: "Também não lhe é facultado fixar prazo para que o Congresso nacional aprove a respectiva proposição legislativa, nem anular sentença judicial, convolando o mandado de injunção em tipo de recurso não previsto na legislação processual".

${ }^{88}$ MI 219/DF, p. 31/32.

${ }^{89} \mathrm{Ml} 283 / \mathrm{DF}$, p. 28.

${ }^{90}$ Cf. MI 708/DF.

${ }^{91}$ Cf. MI 283/DF, p. 43: "Com relação ao prazo, parece-me que S. Exa. não está impondo ao Congresso que aja, desta ou daquela forma, mas dizendo apenas que, se o Congresso não o fizer nesse prazo, a consequência será a prevista no voto". 
DOI:

que vote"92 (ainda que trate-se de coação indireta) ${ }^{93}$, assinalando apenas que, em caso de inércia, fosse possibilitado "ao impetrante obter satisfação provisória de seu direito" 94 . Não havendo imposição de pena ao Congresso, não haveria violação da Separação dos Poderes ${ }^{95}$.

É importante também destacar que em outras ocasiões (por exemplo, no MI 361, julgado em 23/06/93, e no MI 45/DF, julgado em 19/05/94), os ministros Sydney Sanches e Moreira Alves manifestaram entendimento de que não seria possível fixação de prazo para que o Congresso legisle ${ }^{96}$, pois, se ultrapassado, o STF não

${ }^{92}$ Cf. Ml 283/DF, p. 41: "Creio que o jogo dos Poderes é mais adequado essa fixação de um prazo breve ao Congresso Nacional. Como "data vênia", também não recuo, não obstante o peso das ponderações de V.Exa., desta possibilidade, nos casos em que não houver prazo constitucional, porque acho que não estamos ordenando ao Congresso que vote: estamos estabelecendo o prazo para que se torne eficaz a construção acautelatória que fizermos para o caso concreto.

"Por me parecer mais adequado, pela delicadeza dessa interferência de Poderes, é que prefiro manter este prazo para que se ultime o processo legislativo".

${ }^{93}$ Cf. MI 283/DF, p. 49: "No caso, não há dúvida da omissão constitucional do Congresso pela ocorrência da mora no regulamentar o texto constitucional em causa, e, para que o Estado não se beneficie de sua própria omissão, reconheço o direito do impetrante de, se o Congresso nacional não fizer a regulamentação dentro do prazo fixado, de pleitear judicialmente a indenização de direito comum, na sua maior extensão possível, e, portanto, independentemente de restrições que a regulamentação do dispositivo constitucional em apreço, se feita, poderia determinar. É maneira indireta de compelir o Congresso, que por essas omissões não é passível de sanção direta, a cumprir o dever que a Constituição lhe impõem de regulamentar os dispositivos que outorgam os direitos, as liberdades ou as prerrogativas que dão margem é utilização do mandado de injunção" (grifo nosso).

${ }_{94} \mathrm{MI} 283 / \mathrm{DF}$, p. 15.

95 Cf. Ml 283/DF, p. 42: "Em casos como presente, não me parece que haja qualquer violação constitucional decorrente dessa construção por mim aventada, com inspiração no que ocorre na Alemanha. Não se determina que 'o Congresso tem que elaborar a lei sob pena de ...', mas se estabelece que, se o Congresso não a elaborar, poderá, no caso, ser aplicado com a observância das normas de direito comum relativas à indenização".

${ }_{96} \mathrm{Cf}$. MI 361/RJ, p. 32: "Sr. Presidente, na ação direta de inconstitucionalidade, por omissão, o Supremo Tribunal Federal não tem o poder de fixar prazo para que o Legislativo cumpra o seu dever constitucional (parágrafo $2^{\circ}$ do art. 103). Esse poder lhe fora outorgado durante a preparação do texto constitucional na Assembleia Nacional Constituinte, mas, depois, foi retirado. Ora se nem na ação direta de inconstitucionalidade, que tem maior expressão e maior relevo, se pode chegar à fixação de um prazo para o Congresso, menos ainda isso há de ser possível na solução de casos concretos, como nos mandados de injunção. Até porque, se o Congresso não elaborar no prazo, que vier a ser fixado pelo Supremo, qual será a consequência? A Constituição não a prevê. E enfatiza a independência dos Poderes da União (art. $2^{\circ}$ ) de sorte que o Judiciário não pode invadir a área de atuação estrita do Legislativo. "Acompanho o eminente Relator e os que o seguiram, no ponto em que reconhecem a mora do Congresso, mas não fixo prazo para elaboração da norma. O Congresso é que é responsável pelo cumprimento de seu dever constitucional de legislar, não o Supremo. O Congresso só deve ser alertado de que está em mora" (grifo nosso). 
DOI:

poderá suprir a norma ${ }^{97}$ e nem impor sanção ${ }^{98}$. Buscando harmonizar as divergentes manifestações desses ministros (Sydney Sanches e Moreira Alves) sobre a possibilidade ou não de prazo, podemos concluir que entendem legítima sua fixação apenas quando seu descumprimento implica na satisfação provisória do direito do impetrante, mas sem caráter de imposição ao Congresso em seu dever de legislar.

Novamente, a questão com relação ao Poder Executivo não foi levantada. Caso o fosse, a analogia à ação direta de inconstitucionalidade por omissão poderia ser utilizada a favor do prazo, que neste caso é de 30 dias, conforme art. 102, $§ 2^{\circ}$, da Constituição Federal. Por outro lado, a existência do prazo para ADI por omissão também poderia ser utilizada como argumento de que o legislador constituinte teria intencionalmente deixado o mandado de injunção sem prazo, pois não seria cabível neste instituto.

\section{CONCLUSÕES}

Em suma, podemos sistematizar os principais posicionamentos dos ministros do Supremo Tribunal Federal sobre a natureza do mandado de injunção, no que se refere à Separação dos Poderes, da seguinte maneira.

Em síntese, os ministros adeptos da Teoria Não-Concretista entendem que:

a) O poder de legislar do Judiciário depende de expressa previsão constitucional, em razão do princípio da separação dos Poderes, do princípio da legalidade e do princípio democrático;

b) A competência normativa não foi atribuída ao STF em sede de ação direta de inconstitucionalidade por omissão, de modo que não faria sentido entender que foi atribuído em mandado de injunção;

\footnotetext{
${ }^{97}$ Cf. MI 361/RJ, p. 35: "Discordo, porém, que S. Exa. quanto à fixação de prazo para o Congresso Nacional, pois, ultrapassado este, não poderá esta Corte dar consequência à permanência da omissão, uma vez que não dispõe de poder político de legislar em tese ou para o caso concreto".

${ }_{98}$ Cf. MI no 20/DF, p. 52: "Defiro-o, para declarar que o Congresso Nacional se encontra em mora de legislar e para instá-lo a que o faça. Só não posso fixar prazo para isso, pois a Constituição não confere tal poder ao Supremo Tribunal Federal, nem estabelece sanções para o descumprimento da determinação".
} 
DOI:

c) Todas as funções normativas são estranhas ao Poder Judiciário (em abstrato e em concreto) e seu exercício pelo STF seria uma substituição ao legislador;

d) A autorização às demais instâncias para aplicação de lei já existente é medida válida em mandado de injunção, aplicável em casos que o Legislativo permaneça em inércia após ser comunicado da omissão;

e) Decisões e opções políticas cabem apenas aos Poderes eleitos pelo povo (Executivo e Legislativo) e em nenhuma hipótese devem ser exercidas pelo Poder Judiciário (inclusive porque a demora em legislar pode ser parte do processo democrático);

f) Em sede de mandado de injunção, a decisão tem natureza mandamental, com força obrigatória inclusive ao Poder Legislativo, sendo possível estipular prazo para supressão da omissão. Isso não configura violação da Separação dos Poderes, pois se trata de prazo sem penalidade ao Legislativo, que se ultrapassado apenas "libera" alguns efeitos da decisão.

Enquanto isso, os ministros apoiadores da Teoria Concretista defendem, resumidamente, que:

a) O artigo 5, LXXI, da Constituição Federal atribui competência normativa ao Poder Judiciário para julgar mandado de injunção (trata-se, inclusive, de um poder-dever);

b) Não há similaridade entre mandado de injunção e ação direta de inconstitucionalidade por omissão;

c) Função normativa e função legislativa não se confundem, de modo que as competências do Poder Legislativo não são usurpadas pelo Poder Judiciário e nem substituição do legislador pelo Judiciário;

d) Decisão que indique a aplicação de lei já existente não constitui atividade legiferante, mesmo que seja aplicada diretamente pelo STF e que a lei expressamente não se aplique ao caso;

e) A escolha ou decisão política não cabe ao Poder Judiciário, mas a Constituição autoriza que ele supra as omissões do Poder Legislativo sem limitação temática; 
DOI:

f) Em sede de mandado de injunção, a decisão tem natureza constitutiva e eventual comunicação ao Poder Legislativo não possui natureza obrigatória, não sendo possível estabelecer um prazo, sob pena de violar a harmonia entre os Poderes.

Entre os ministros concretistas, por sua vez, existe uma divergência com relação à extensão dos efeitos da decisão em mandado de injunção:

a) De um lado, os ministros que seguem a Teoria Concretista Individual pregam que o ato judicial aplica exclusivamente ao caso concreto e com efeito inter partes; e

b) Por sua vez, os ministros seguidores a Teoria Concretista Geral advogam que 0 ato judicial possui parâmetros abstratos e pode eventualmente possuir efeitos erga omnes, desde que tal poder seja exercido com parcimônia e respeitando um quadro de institucionalidade (se o Congresso se mantiver em inércia após a comunicação de sua omissão).

\section{REFERÊNCIAS}

ACKEL FILHO, Diomar. Writs Constitucionais: "habeas corpus", mandado de segurança, mandado de injunção, "habeas data". São Paulo: Saraiva, 1988.

AFONSO DA SILVA, José. Curso de Direito Constitucional Positivo. 19a ed. São Paulo, 2001.

BARBOZA, Maria Cristina. A Omissão no Centro das Atenções: o mandado de injunção como um instrumento de garantia de direitos fundamentais e de solução de omissões legislativas. Dissertação de Mestrado (Mestrado em Direito Constitucional). Pontifícia Universidade Católica de São Paulo. São Paulo, 2014.

BASTOS, Celso Ribeiro. MARTINS, Ives Gandra da Silva. Comentários à Constituição do Brasil: promulgada em 5 de outubro de 1988. São Paulo: Saraiva, 1988/90.

BRASIL. Supremo Tribunal Federal. AgMI 1229/DF. Acórdão no Agravo Regimental em Mandado de Injunção no 1229/DF. Relator(a): Ministra Rosa Weber. Julgado em 31/10/2012. Publicado em 27/05/2013. Brasília, 2012. Disponível em $<$ http://redir.stf.jus.br/paginadorpub/paginador.jsp?docTP=TP\&doclD=3902175>. Acesso em 23/01/2019. 
DOI:

MI 1229/DF. Acórdão no Mandado de Injunção no 1229/DF.

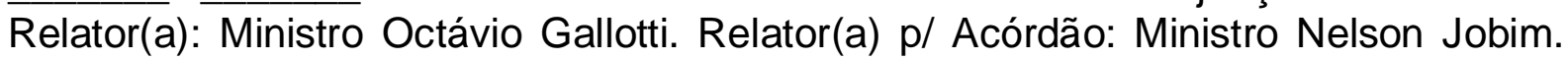
Julgado em 26/10/2000. Publicado em 24/05/2002. Brasília, 2002, p. 13. Disponível em <http://redir.stf.jus.br/paginadorpub/paginador.jsp?docTP=AC\&doclD=81863>. Acesso em 23/01/2019.

. MI 20/DF. Acórdão no Mandado de Injunção nํ20/DF. Relator(a): Ministro Celso de Mello. Julgado em 19/05/1994. Publicado em 22/11/1996. Brasília, 1996, $\quad$ p. $53 . \quad$ Disponível em $<$ http://redir.stf.jus.br/paginadorpub/paginador.jsp?docTP=AC\&doclD=81733 > Acesso em 18/01/2019.

MI 219/DF. Acórdão no Mandado de Injunção nํ219/DF. Relator(a): Ministro Octávio Gallotti. Julgado em 22/08/1990. Publicado em 19/05/1995. Brasília, 1995.

Disponível em $<$ http://redir.stf.jus.br/paginadorpub/paginador.jsp?docTP=AC\&doclD=81758 >. Acesso em 09/01/2019.

. MI 232/RJ. Acórdão no Mandado de Injunção no 232/RJ. Relator(a): Ministro Moreira Alves. Julgado em 02/08/1991. Publicado em 27/03/1992. Brasília, $1992 . \quad$ Disponível em <http://redir.stf.jus.br/paginadorpub/paginador.jsp?docTP=AC\&doclD=81759>.

Acesso em 16/01/2019.

MI 283/DF. Acórdão no Mandado de Injunção nํ2 283/DF. Relator(a): Ministro Sepúlveda Pertence Julgado em 20/03/1991. Publicado em 14/11/1991. Brasília, 1991, $\quad$ p. 47.40 Disponível $<$ http://redir.stf.jus.br/paginadorpub/paginador.jsp?docTP=AC\&doclD=81766 > Acesso em 16/01/2019.

MI 284/DF. Acórdão no Mandado de Injunção no 284/DF. Relator(a): Ministro Marco Aurélio. Relator(a) p/ Acórdão: Ministro Celso de Mello. Julgado em 22/11/1992. Publicado em 26/06/1992. Brasília, 1991, p. 11/12. Disponível em <http://redir.stf.jus.br/paginadorpub/paginador.jsp?docTP=AC\&doclD=81767>.

Acesso em 17/01/2019.

MI 361/RJ. Acórdão no Mandado de Injunção no 361/RJ. Relator(a): Ministro Néri da Silveira. Julgado em 08/04/1994. Publicado em 17/06/1994. Brasília, 1994, p. 19. Disponível em $<$ http://redir.stf.jus.br/paginadorpub/paginador.jsp?docTP=AC\&docID=81794>. Acesso em 18/01/2019.

MI 543/DF. Acórdão no Mandado de Injunção o 543/DF. Relator(a): Ministro Octávio Gallotti. Relator(a) p/ Acordão: Ministro Nelson Jobim. Julgado em 26/10/2000. Publicado em 24/05/2002. Brasília, 2002. Disponível em $<$ http://redir.stf.jus.br/paginadorpub/paginador.jsp?docTP=AC\&docID=81863>. Acesso em 18/01/2019. 
DOI:

MI 670/ES. Acórdão no Mandado de Injunção no 670/ES. Relator(a): Ministro Maurício Corrêa. Relator(a) p/ Acordão: Ministro Gilmar Mendes. Julgado em 25/10/2007. Publicado em 30/10/2008. Brasília, 2008. Disponível em $<$ http://redir.stf.jus.br/paginadorpub/paginador.jsp?docTP=AC\&doclD=558549>. Acesso 23/01/2019.

MI 708/DF. Acórdão no Mandado de Injunção no 708/DF. Relator(a): Ministro Gilmar Mendes. Julgado em 25/10/2007. Publicado em 31/10/2008. Brasília, 2008. Disponível em $<$ http://redir.stf.jus.br/paginadorpub/paginador.jsp?docTP=AC\&doclD=558551>. Acesso em 30/01/2019.

MI 712/PA. Acórdão no Mandado de Injunção no 712/PA. Relator(a): Ministro Eros Grau. Julgado em 25/10/2007. Publicado em 30/10/2008. Brasília, 2008. Disponível em $<$ http://redir.stf.jus.br/paginadorpub/paginador.jsp?docTP=AC\&doclD=558553 > Acesso 30/01/2019.

MI 721/DF. Acórdão no Mandado de Injunção no 721/DF. Relator(a): Ministro Marco Aurélio. Julgado em 30/08/2007. Publicado em 30/11/2007. Brasília, 2007. Disponível em $<$ http://redir.stf.jus.br/paginadorpub/paginador.jsp?docTP=AC\&doc/D=497390>. Acesso em 23/01/2019.

MI 833/DF. Acórdão no Mandado de Injunção no 833/DF. Relator(a): Ministra Carmen Lúcia. Relator (a) p/ Acórdão: Ministro Roberto Barroso. Julgado em 11/06/2015. Publicado em 29/09/2015. Brasília, 2015, p. 70/71. Disponível em $<$ http://redir.stf.jus.br/paginadorpub/paginador.jsp?docTP=TP\&doclD=9382054> . Acesso em 23/01/2019. Relator(a): Ministro Gilmar Mendes. Julgado em 06/02/2013. Publicado em 30/04/2013. Brasília, 2013. Disponível em $<$ http://redir.stt.jus.br/paginadorpub/paginador.jsp?docTP=TP\&doclD=3716117> . Acesso em 23/01/2019.

MI 95/RR. Acórdão no Mandado de Injunção no 95/RR. Relator(a): Ministro Carlos Velloso. Relator(a) p/ Acórdão: Ministro Sepúlveda Pertence. Julgado em 07/10/1992. Publicado em 18/061993 Brasília, 1993. Disponível em $<$ http://redir.stf.jus.br/paginadorpub/paginador.jsp?docTP=AC\&doclD=81742>. Acesso em 18/01/2019.

QOMI 107/DF. Acórdão na Questão de Ordem em Mandado de Injunção no 107/DF. Relator(a): Ministro Moreira Alves. Julgado em 23/11/1989. Publicado em 21/09/1990. Brasília, 1990. Disponível em $<$ http://redir.stf.jus.br/paginadorpub/paginador.jsp?docTP=AC\&doclD=81908>. Acesso em 27/12/2018. 
DOI:

FERREIRA FILHO, Manoel Goncalves. Curso de Direito Constitucional. São Paulo: Saraiva, 2015.

MACIEL, Adhemar Ferreira. Mandado de Injunção e Inconstitucionalidade por Omissão. In Revista de Informação Legislativa, no 101, Brasília, jan/mar. 1989.

MEIRELLES, Hely Lopes. WALD, Arnoldo. MENDES, Gilmar Ferreira. Mandado de Segurança e Ações Constitucionais. São Paulo: Malheiros, 2009.

MORAES, Alexandre de. Direito Constitucional. 22ª ed. São Paulo, Atlas, 2002.

NUNES JUNIOR, Vidal Serrano. SCIORILLI, Marcelo. Mandado de segurança: ação civil pública, ação popular, "habeas data", mandado de injunção. São Paulo: Verbatim, 2009.

PIOVESAN, Flavia Cristina. Proteção Judicial contra Omissões Legislativas: ação direta de inconstitucionalidade por omissão e mandado de injunção. São Paulo: Revista dos Tribunais, 1995.

TUCCI, Rogerio Lauria. TUCCI, Jose Rogerio Cruz e. Constituição de 1988 e Processo: regulamentos e garantias constitucionais do processo. São Paulo: Saraiva, 1989. 